\title{
Дослідження шумового навантаження та розробка комплексу шумознижуючих заходів на прикладі одного з мікрорайонів м. Житомир
}

У сучасних умовах розвитку урбанізованих територій все більще зростає значущість захисту від шумового впливу. У зв'язку з індустріалізаџією міст, зростанням кількості транспортних засобів, транспортної рухливості населення, ростом технічного оснащення міського господарства збільшуються рівні шумового забруднення.

Для проведення досліджень було обрано один із мікрорайонів м. Житомира, віддалений від центра міста та частково оточений зеленою зоною, що зменшує ймовірність впливу інших прилеглих територій зі значним транспортним потоком на формування рівня шумового навантаження.

На основі попереднього обстеження території мікрорайону було виявлено ключові ділянки, 6 яких потім проводилися виміри шуму. Головною вимогою до спектра ключових ділянок була рівномірність розміщення, охоплення всіх функиіональних зон і можливість паралельного виміру шуму біля його джерела і всередині житлового кварталу.

На основі статистичної обробки отриманих експериментальних даних розроблено картографічні моделі просторового розподілу шумового забруднення в межах мікрорайону. $3 а$ результатами досліджень було виділено зони з різним рівнем шумового забруднення. Найбільший рівень шуму спостерігається поблизу місиь виїду автомобілів з провулків на головну дорогу.

Кінцевим етапом проєкту стала розробка заходів зі зниження шумового навантаження на житлові будівлі та прибудинкові території. За результатами акустичних розрахунків визначено геометричні параметри екранів, надано вимоги щодо акустичних характеристик конструкціі екрана $і$ запропоновано базові конструкції, що відповідають таким характеристикам. Розрахункова ефективність екранів становить 7-8 дБ. Було проведено визначення проєктного рівня шуму із врахуванням заходів та створення проєктної карти шуму.

Ключові слова: шум; шумове забруднення; шумомір; карта шуму; звукопоглинальні конструкиії; шумозахисний екран; рівень шуму.

Вступ. В сучасних умовах розвитку урбанізованих територій все більше зростає значущість захисту від шумового впливу. У зв'язку зі зростанням кількості автомобілів (які є основним джерелом шуму), індустріалізацією міст, зростанням транспортної рухливості населення і технічного оснащення міського господарства збільшується рівень шумового забруднення [1].

Сільські й міські території зазнають активного впливу шосейних доріг і залізниць, аеродромів і портів. До цих джерел шуму належать також залізничні вузли і станції, великі автовокзали і автогосподарства, мотелі і кемпінги, промислові об'єкти й великі бази будівельної індустрії, енергетичні установки. Створювати додаткове шумове навантаження може також недосконале планування міст, розміщення у їх межах джерел сильного шуму [2].

Шумове забруднення завжди вважалося менш небезпечною формою, ніж, наприклад, хімічне або електромагнітне, а люди практично не переймалися тим, як шум впливає на їх здоров'я. Проте за даними досліджень деяких урядових і неурядових організацій (наприклад, Бюро національної статистики Великобританії) за останні 20 років рівень шуму у європейських містах зріс у 10-15 разів. Такий рівень шуму турбує більше $50 \%$ мешканців міст, стаючи все більш впливовим негативним фактором навколишнього середовища [3]. За останній час середній рівень шуму від транспорту збільшився на 12 14 дБ, а суб'єктивна гучність виросла в 3-4 рази. На головних магістралях великих міст рівні шумів перевищують 90 ДБ і мають тенденцію до посилення щорічно на 0,5 дБ [4].

Шум, що виникає на проїжджій частині магістралі, розповсюджується не тільки на примагістральну територію, але й углиб житлової забудови [5]. Так у зоні найбільш сильної дії шуму знаходяться частини кварталів і мікрорайонів, розташованих вздовж магістралей загальноміського значення. Рівні шуму, заміряні в житлових кімнатах при відкритих вікнах, орієнтованих на вказані магістралі, всього на 10-15 дБ нижчі, ніж поблизу магістралі. 
Ефективним шляхом вирішення проблеми боротьби з шумом є зниження його рівня в самому джерелі за рахунок зміни технології і конструкції машин [6]. До заходів цього типу належать: заміна шумних процесів безшумними, ударних - неударними (наприклад, заміна клепання - паянням, кування i штампування - обробкою тиском; заміна металу в деяких деталях незвучними матеріалами, застосування віброізоляції, глушників, демпфування, звукоізолюючих кожухів та ін.). В деяких випадках зниження рівня шуму досягається застосуванням звукопоглинальних пористих матеріалів, покритих перфорованими листами алюмінію, пластмас.

Велике значення в боротьбі з шумом мають архітектурно-планувальні і будівельні заходи [7]. Архітектурно-планувальний аспект колективного захисту від шуму пов'язаний з необхідністю обліку вимог шумозахисту в проєктах планування і забудови міст і мікрорайонів (рис. 1). ПередБачається зниження рівня шуму шляхом використання екранів, територіальних розривів, шумозахисних конструкцій, зонування і районування джерел і об'єктів захисту, захисних смуг озеленення. Акустичні засоби захисту від шуму підрозділяються на засоби звукоізоляції, звукопоглинання і глушники шуму [8].

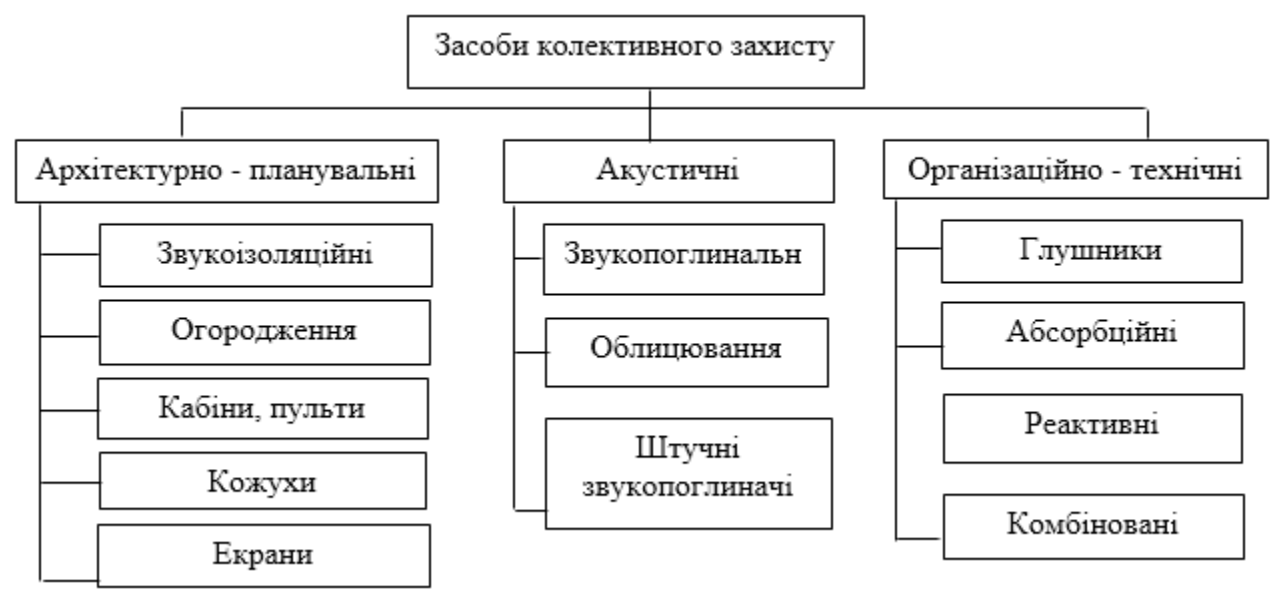

Рис. 1. Засоби захисту від шуму на шляху його розповсюдження

Таким чином, проблема шумового забруднення є досить важливою в наш час. Кількість джерел шуму 3 кожним днем збільшується і необхідно застосовувати нові засоби боротьби з ними. А зважаючи на негативний вплив шуму на живі організми, це питання потребує уваги та негайного вирішення з боку як суспільства, так і влади.

За сучасних умов боротьба з шумом є технічно складною, комплексною і дорогою. Важливо знижувати шум у джерелі його виникнення, створювати безшумні або малошумні машини і технологічні процеси, транспортне і промислове устаткування, починаючи ще зі стадії проєктування [10]. Однак набагато частіше доводиться вирішувати протилежну задачу. Поступове зростання шумового навантаження призводить до перевищення нормативного рівня шуму у вже створених мікрорайонах міста, зі сформованою інфраструктурою. У таких випадках доводиться використовувати такі засоби як екранування, озеленення тощо, що захищають від шуму, створюючи перешкоди на шляху його поширення. Для грамотного планування таких заходів необхідно насамперед дослідити рівень шуму на території об’єкта, визначити основні джерела, які його спричиняють, розрахувати ймовірний ефект від впровадження різних заходів зниження шумового навантаження $\mathrm{i}$, лише після цього, розробляти загальний план впровадження шумозахистних заходів.

Мета роботи - дослідження шумового навантаження та розробка комплексу шумознижуючих заходів в мікрорайоні Хмільники міста Житомир.

Об'єкт досліджень. Оскільки досить складно охопити дослідженнями територію цілого міста, то оцінка шумового навантаження виконувалася на прикладі одного з мікрорайонів м. Житомир, а саме мікрорайону Хмільники. Хмільники - у минулому місцевість поблизу Житомира, нині мікрорайон цього міста зі значною житловою забудовою. До вулиць 3 найбільшим транспортним потоком на мікрорайоні належать Сурина Гора, Глибочицька, площа Зарембського та бульвар Польський (рис. 2).

Мікрорайон Хмільники був обраний для досліджень з урахуванням таких факторів:

- мікрорайон віддалений від центра міста та частково оточений зеленою зоною, що зменшує ймовірність впливу інших прилеглих територій зі значним транспортним потоком на формування рівня шумового навантаження;

- на території мікрорайону проживає значна кількість населення, що обумовлює високий рівень та різноманітність джерел шуму; 
- $\quad$ нерівномірність забудови, інфраструктури та озеленення мікрорайону дозволяє визначити основні фактори, які впливають на розповсюдження звукової хвилі;

- невисока щільність житлової забудови дає можливість запроєктувати додаткові засоби для зменшення шумового навантаження на житлові будівлі та прибудинкові території.
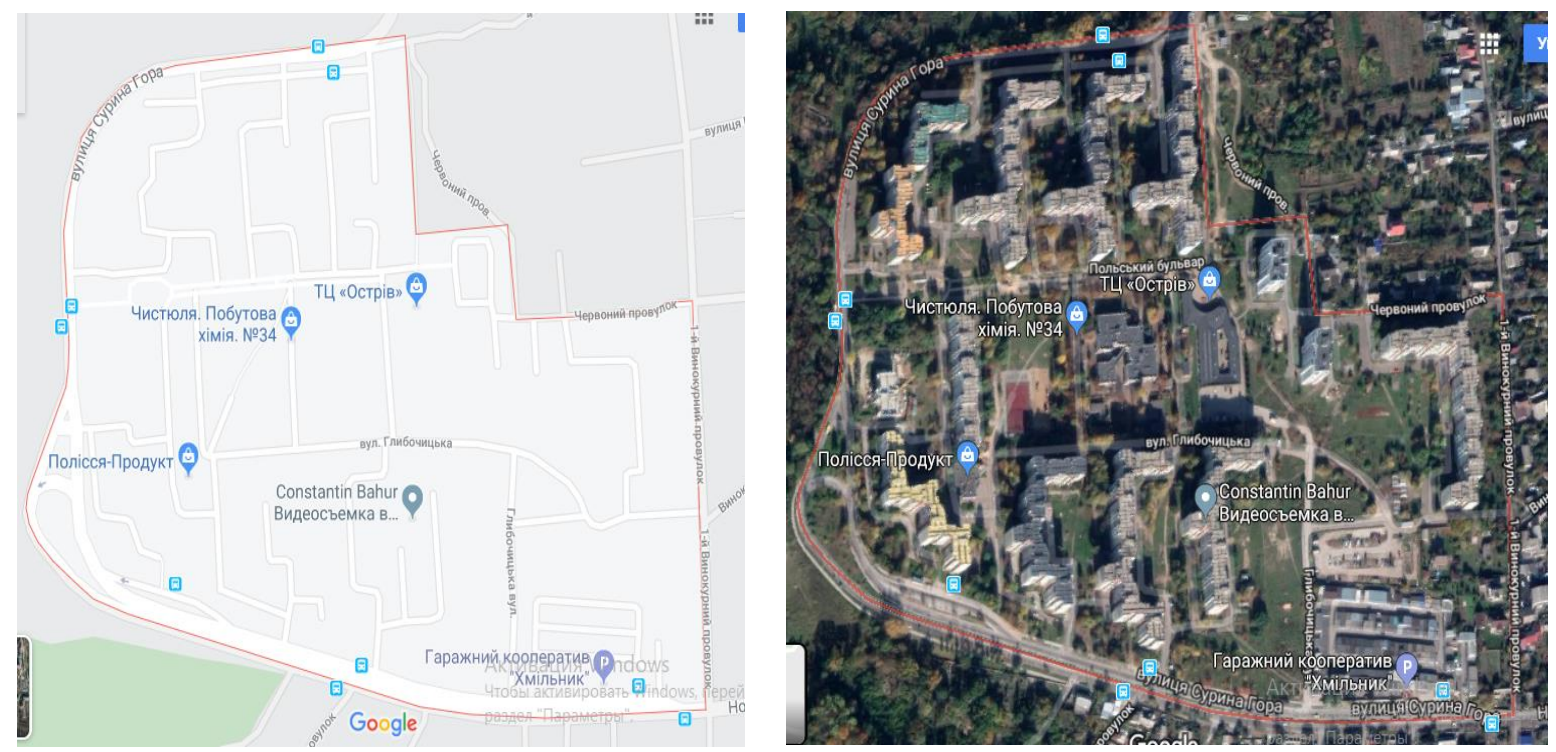

Рис. 2. Територія дослідження

Методика досліджень. Проведені дослідження складалися з декількох етапів відповідно до загальної програми досліджень (рис. 3).

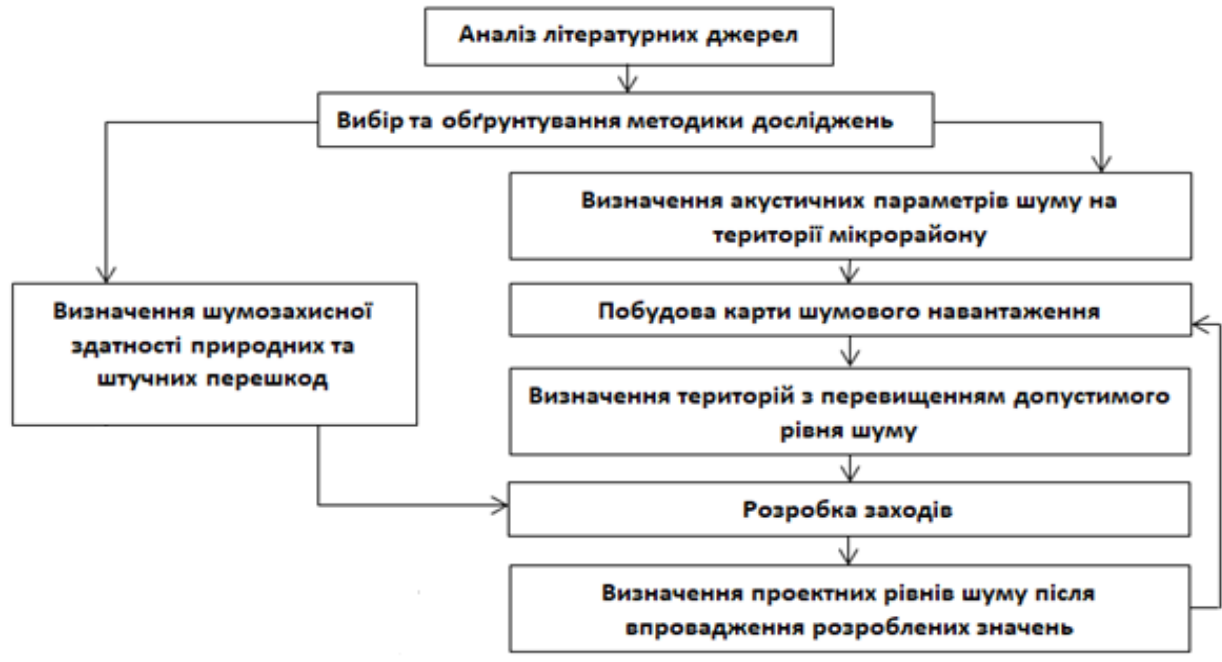

Рис. 3. Програма досліджень

Дослідження шумового навантаження мікрорайону Хмільники можна умовно розділити на дві взаємопов'язані частини:

- натуральні польові вимірювання акустичних параметрів, що проводилися по всій території мікрорайону із однаковою відстанню між точками вимірювання;

- обробка отриманих результатів з наступною побудовою карт шуму.

На основі рекогносцувального обстеження території міста виявлено ключові ділянки, в яких потім проводилися виміри шуму.

Головною вимогою до спектра ключових ділянок $є$ рівномірність розміщення, охоплення всіх функціональних зон і можливість паралельного виміру шуму біля його джерела і за «звуковим екраном» (всередині житлового кварталу). 
У роботі використовувався цифровий шумомір [11] ADA ZSM 130+. Шумомір призначений для роботи із забезпечення техніки безпеки, охорони здоров'я, промислової безпеки та контролю якості звуку в різних умовах. Прилад дозволяє: вимірювати рівень шуму в діапазоні від 35 до 130 дБ в діапазоні 31,5 Гц - 8 кГц, вимірювати рівень звукового тиску, зваженого по частоті А / C, проводити тимчасове зважування (швидке 125 мс, 1 с), передавати дані на реєстратор, утримувати максимальне виміряне значення, зберігати виміряне значення [12].

Кінцевим етапом проєкту стала розробка заходів зі зниження шумового навантаження на житлові будівлі та прибудинкові території, визначення проєктного рівня шуму із врахуванням заходів та створення проєктної карти шуму.

Карта шуму житлового району містить:

- уточнену схему джерел шуму зі вказівкою розрахункових рівнів шуму;

- карти шуму мікрорайонів та інших територій, що є у складі житлового району;

- карту акустичного дискомфорту житлового району;

- основні містобудівні шляхи зниження шуму до нормативного рівня.

Результати досліджень. Відправними точками проведення польового експерименту були: вулиця Глибочицька, вулиця Сурина Гора, площа Зарембського та бульвар Польський, ТЦ «Острів».

На основі статистичної обробки отриманих експериментальних даних розроблено картографічні моделі просторового розподілу шумового забруднення в межах мікрорайону.

На рисунку 4 можна побачити загальну схему проведення спостережень шумового навантаження в мікрорайоні Хмільники. Точки спостереження рівномірно охоплюють територію мікрорайону. Закладено точки вимірювання на мінімальній відстані від основного джерела забруднення (траси, що кільцем охоплює мікрорайон).

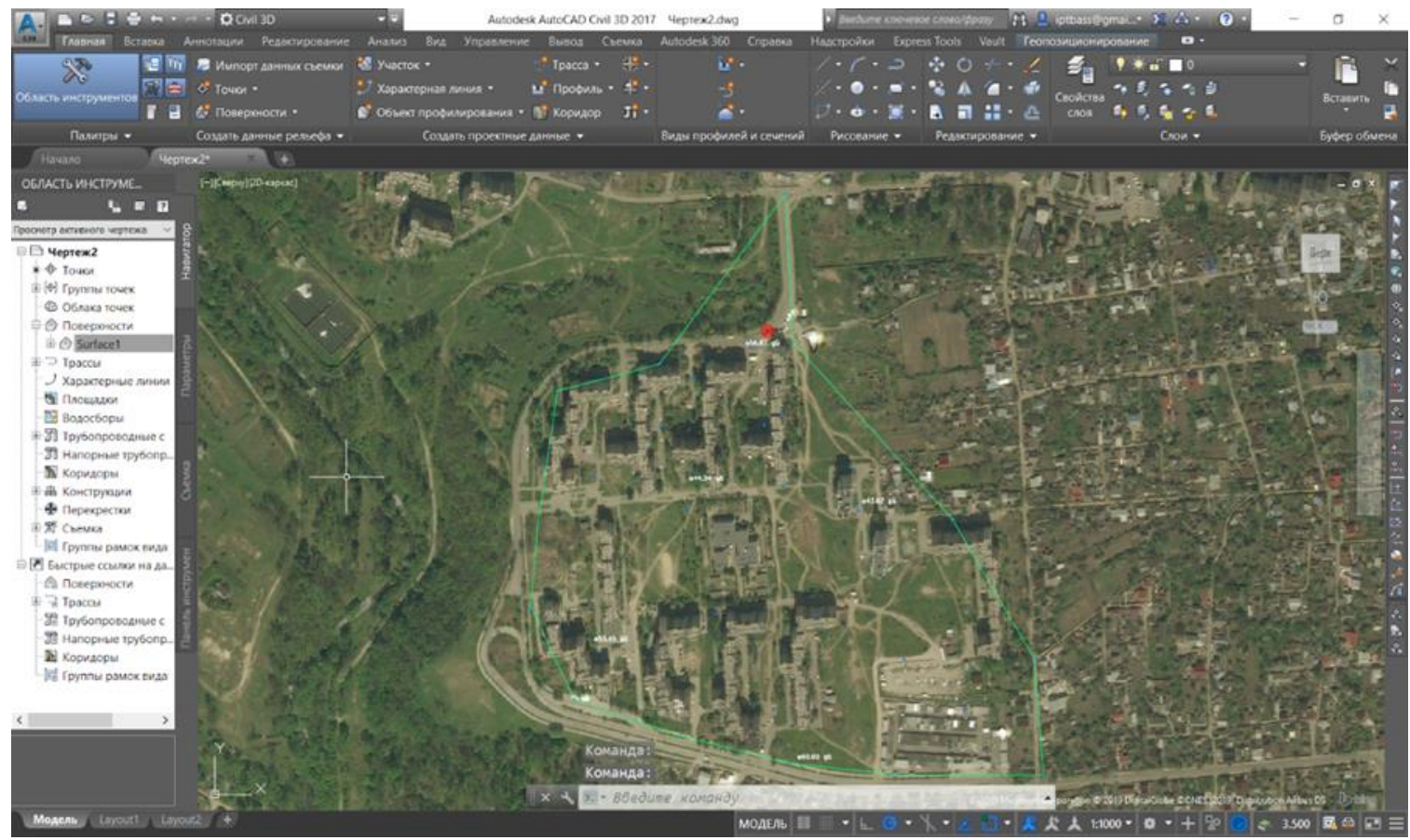

Рис. 4. Координати точок вимірювання шиму

Після огляду території та вибору дослідних точок було виміряно рівень шуму, і відповідно до одержаних показників побудовано карту, на якій відображено актуальний рівень шуму для досліджуваного мікрорайону (рис. 5).

Створена карта демонструє, що найбільший рівень шуму спостерігається поблизу місць виїзду автомобілів $з$ провулків на головну дорогу. Там рівень шуму досягає критичних рівнів. У середині району, де знаходяться житлові будинки і обмежений рух автомобілів, рівень шуму найменший і практично відповідає всім нормативним показникам і критеріям.

Отримані результати досліджень наочно показують, що основним джерелом шуму є автомобільний транспорт, який створює шумове навантаження 73-91 дБ. У мікрорайоні Хмільники м. Житомир всі види транспорту створюють приблизно однаковий рівень шуму під час їх експлуатації. Ситуація не стає кращою навіть з появою та популяризацією електромобілів, оскільки їх кількість у загальному потоці є низькою. 
На динаміку зміни рівня шуму впливає активність автомобільних потоків і скупчення людей. Так наприклад: уздовж доріг у робочий час і у неділю вранці рівень шуму вищий, ніж у неділю ввечері; біля громадських установ в будні рівень шуму вищий, ніж у вихідні; біля супермаркету рівень шуму практично не змінюється. Діючими нормативними документами (Санітарні норми допустимого шуму в приміщеннях житлових будинків і на території житлової забудови [13]) встановлено допустимі значення звукового тиску максимальних і еквівалентних рівнів шуму. Для територій поблизу житлових будівель у денний час ( з 08:00 до 22:00) еквівалентний рівень не має перевищувати 40 дБ, а максимальний - 75 дБ. У нічний час (з 22:00 до 08:00) ці рівні не має перевищувати відповідно 45 і 60 дБ.

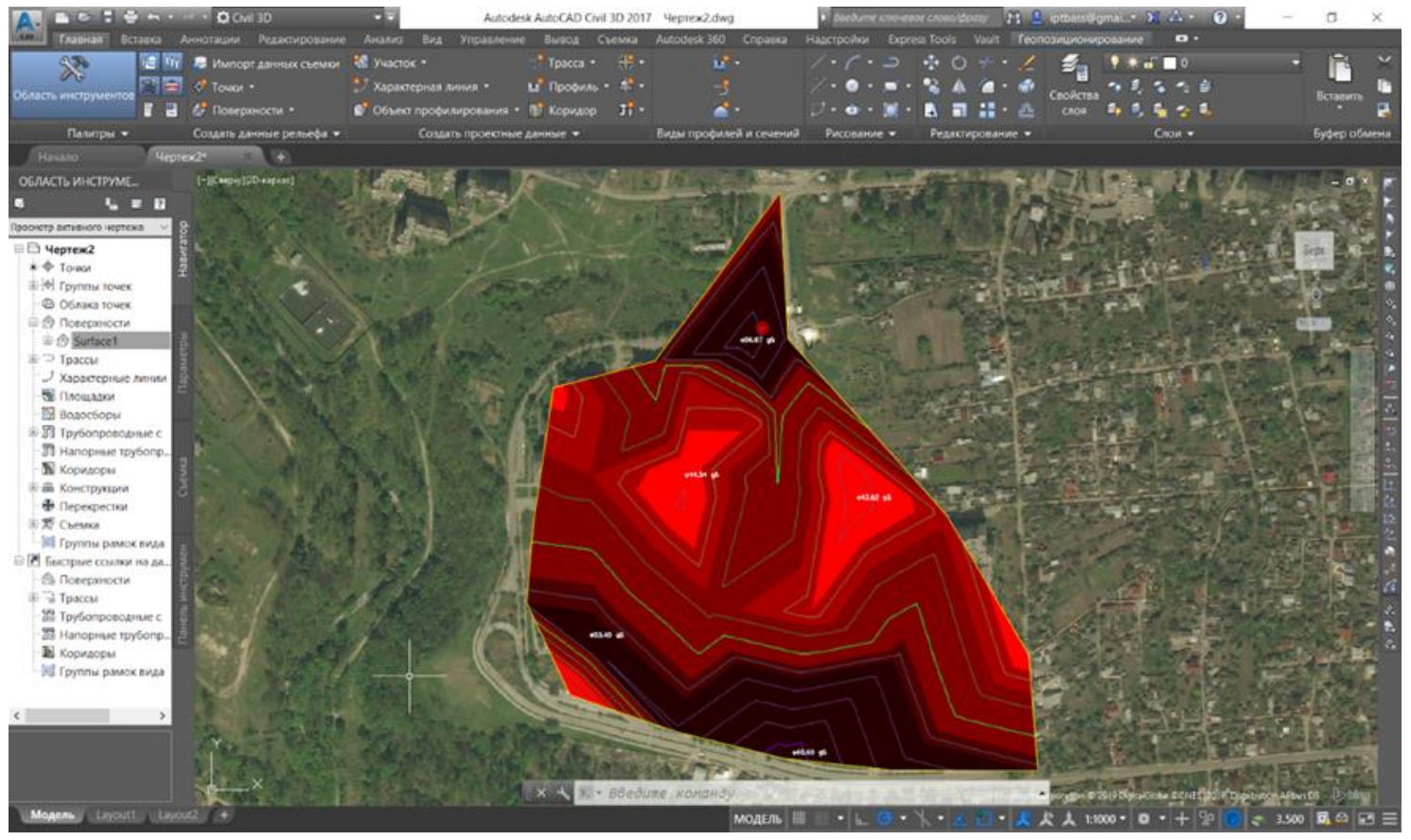

Рис. 5. Карта рівня шуму в мікрорайоні Хмільники

3 отриманих даних можна зробити висновок, що рівень шуму в центральній частині мікрорайону знаходиться в межах норми. Це безпосередньо пов'язано з тим, що мікрорайон є територіально невеликим й інфраструктурно нерозвиненим. Однак території, які безпосередньо прилягають до транспортних магістралей, мають високий рівень шумового навантаження та вимагають заходів щодо проєктування шумознижуючих конструкцій та елементів.

Було проаналізовано ситуацію з шумовим забрудненням на ділянці Польського бульвару. При виїзді на головну вулицю Сурина Гора рівень шуму коливається від 54 дБ до 65 дБ. Далі транспортний потік розганяється на дистанції 100-150 м, коли виїжджає з повороту, і рівень шуму збільшується, оскільки максимальний рівень шуму автомобілі створюють саме під час розгону. Автомобілі також можуть створювати значний рівень шуму під час руху з великою швидкістю (це характерно для нічного часу, коли інтенсивність транспортного потоку незначна), оскільки відомо, що приріст швидкості на кожні 10 км/год створює приріст рівня шуму на 3 дБ. Авторами було визначено рівень шуму на вулицях, що безпосередньо прилягають до житлових будинків (табл. 1). Порівнявши рівні шуму в ранковий і післяобідній час, 3'ясовано що у годину «пік» безпосередній рівень шуму від автотранспорту становить у середньому 75,85 дБ та перевищує допустимий рівень. Найвищий рівень шуму в ранковий час по вулиці Сурина Гора становить 80,4 дБ. Це пов'язано з тим, що ця вулиця є головною і проходить повздовж майже всього мікрорайону. 3 15:00 до 16:00, коли інтенсивність руху автотранспорту протягом робочого часу найменша, відповідно рівень шуму значно менший.

Таблиия 1

Рівень шуму на вулииях мікрорайону Хмільники

\begin{tabular}{|c|c|c|}
\hline \multirow{2}{*}{ Назва вулиці } & \multicolumn{2}{|c|}{ Час вимірювання } \\
\cline { 2 - 3 } & $08: 00-09: 00$ & $15: 00-16: 00$ \\
\hline Сурина Гора & 80,4 & 60,1 \\
\hline Глибочицька & 77,4 & 58,0 \\
\hline Польський бульвар & 70,4 & 45,2 \\
\hline Зарембського площа & 75,2 & 57,5 \\
\hline
\end{tabular}


Визначення рівня шумового забруднення проводилося на території ТЦ «Острів», яка характеризується найбільшим скупченням людей. Вимірювання рівня шуму проводили 3 рази на день (о 8:00, о 14:00 та о 18:00), оскільки в різний час доби рівень шумового навантаження різний. Під час проведеного дослідження було встановлено, що найбільший рівень шуму досягав позначки 80,5 дБ. Основний шумовий фон створюють транспорті засоби та велика кількість людей (рис. 6).

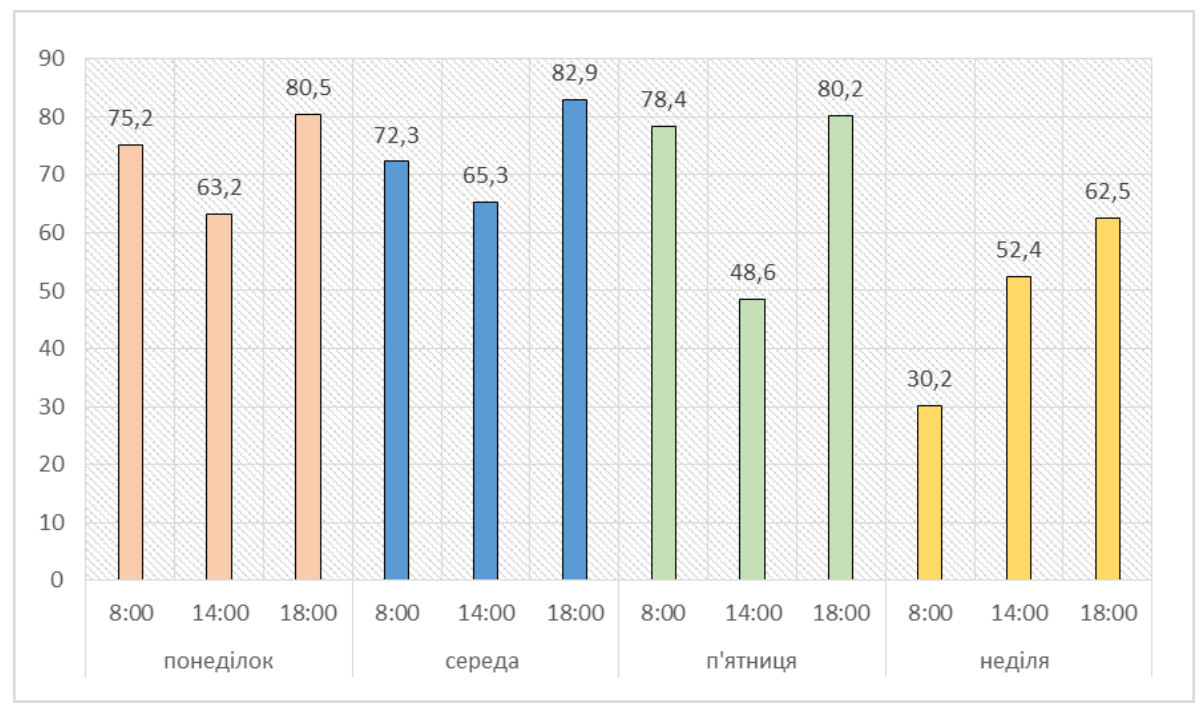

Рис. 6. Рівень шуму біля ТЦ «Острів» (одиниия виміру дБ)

На рисунку 6 видно, що найвищі рівні шуму в будні дні спостерігаються у ранковий та вечірній час, оскільки саме в цей час велика кількість людей їде і відповідно повертається з роботи. Причиною таких показників шуму є не лише транспортні засоби (дорожній шум), а й галас юрби людей. В обідній час рівень шуму знаходиться переважно в допустимих межах Державних санітарних норм (60 дБ). У вихідні дні рівень шуму біля ТЦ «Острів» найнижчий.

Розробку конструктивних заходів для захисту об'єктів міської забудови від шуму можна робити як під час їх проєктування, так і під час реконструкції. Але якщо інфраструктура території вже сформована, то найбільш ефективним засобом боротьби з шумом $є$ встановлення шумозахисних екранів. Конструктивне рішення і геометричні параметри шумозахисних екранів обираються в кожному конкретному випадку індивідуально [14]. Під час їх вибору одним з визначальних критеріїв $є$ раціональне співвідношення «вартість - ефективність».

На рисунках 7-9 наведено очікувані звукові поля на прилеглій території: під час спорудження шумозахисного екрана висотою 7 м при довжині 100 м (варіант № 1) (рис. 7), висотою 7 м при довжині 150 м (варіант № 2) (рис. 8) та висотою 8 м при довжині 150 м (варіант № 3) (рис. 9).
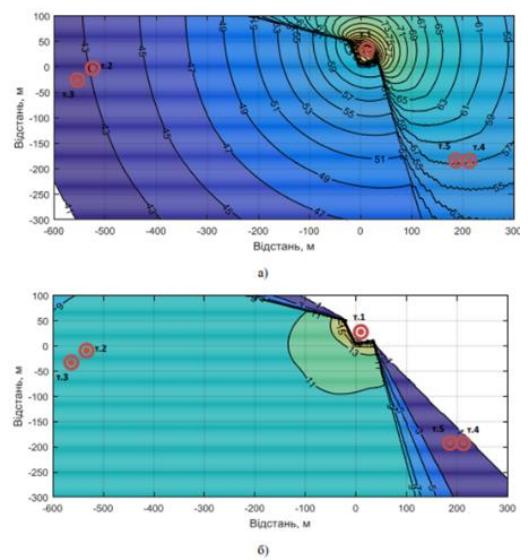

Pис. 7. Варіант екрана № 1 (висота екрана $7 \mathrm{M}$, загальна довжина 100 м)
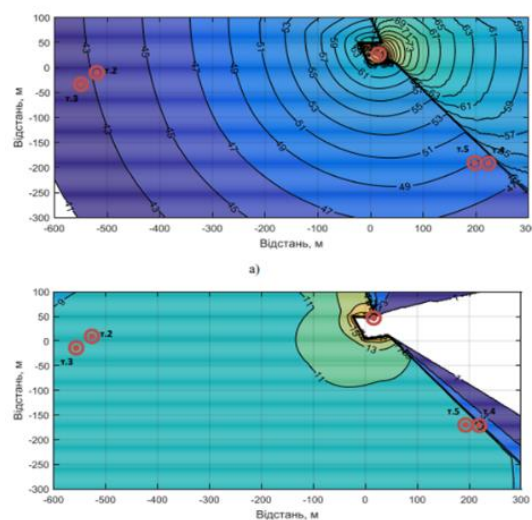

Рис. 8. Варіант екрана № 2 (висота екрана $7 \mathrm{M}$, загальна довжина 150 м)
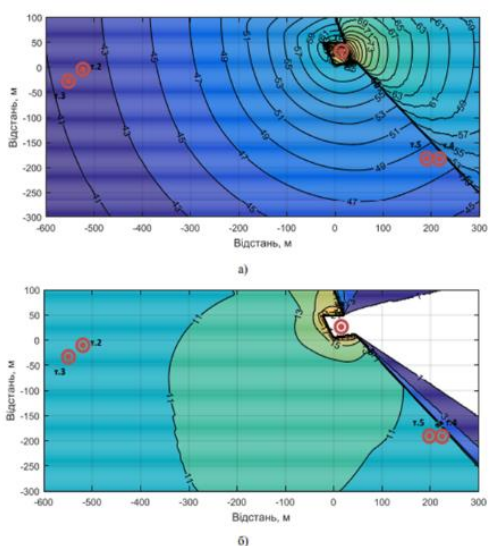

Pис. 9. Варіант екрана № 3 (висота екрана $8 \mathrm{M}$, загальна довжина 150 м) 
На рисунку 7 наведено очікуване звукове поле та ефективність екрана висотою 7 м, за умови його розташування вздовж двох сторін майданчика довжиною 45 м та 45 м. Таке розташування екрана дозволяє отримати деяку ефективність екранування шуму в напрямках житлових будинків. Однак із карти шуму видно, що довжина екрана не є достатньою і звук проникає не лише через верхню кромку екрана, а також з боку.

На рисунку 8 наведено очікуване звукове поле та ефективність екрана висотою 7 м, за умови його розташування вздовж трьох границь концертного майданчика (рис. 8, а). Збільшення довжини екрана призвело до підвищення його ефективності, а отже до зменшення рівня звуку біля житлового будинку на Польському бульварі, 85/5 на величину до 8 дБ в порівняно з варіантом № 1.

На рисунку 9 наведено варіант екрана № 3 з висотою 8 м та тією ж конфігурацією екрана, як і в варіанті № 2. Збільшення висоти екрана призвело до зниження рівня звуку біля житлових будинків на 1 дБ.

Отже, аналіз можливих варіантів екрана показав, що для мікрорайону Хмільники м. Житомир розташування екрана за варіантом № 1 буде недоцільним (рис. 10), оскільки цей варіант екрана має незначну шумопоглинаючу здатність та не зможе знизити рівень шумового навантаження на мешканців мікрорайону до допустимого рівня. Найбільш ефективним є екран за варіантом № 3 (рис. 11). Він захищає територію безпосередньо біля житлових будинків. Тому саме цей варіант було взято за основу для подальшого розрахунку та аналізу.

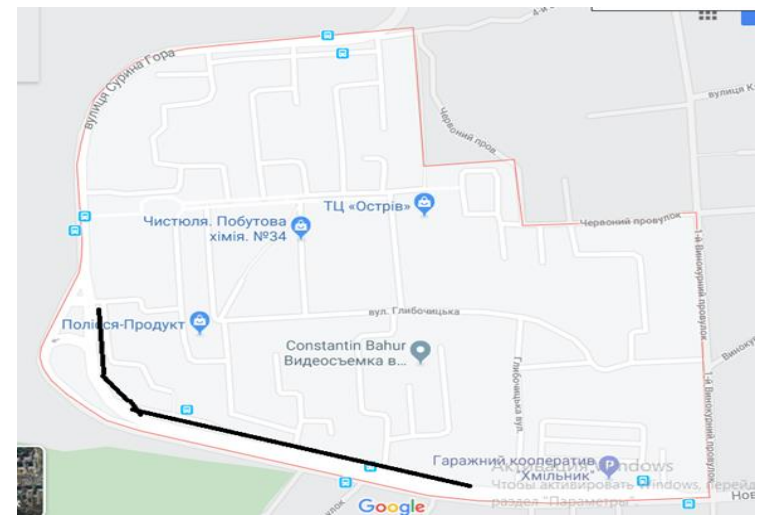

Рис. 10. Розміщення екрана у мікрорайоні Хмільники згідно з варіантом № 1

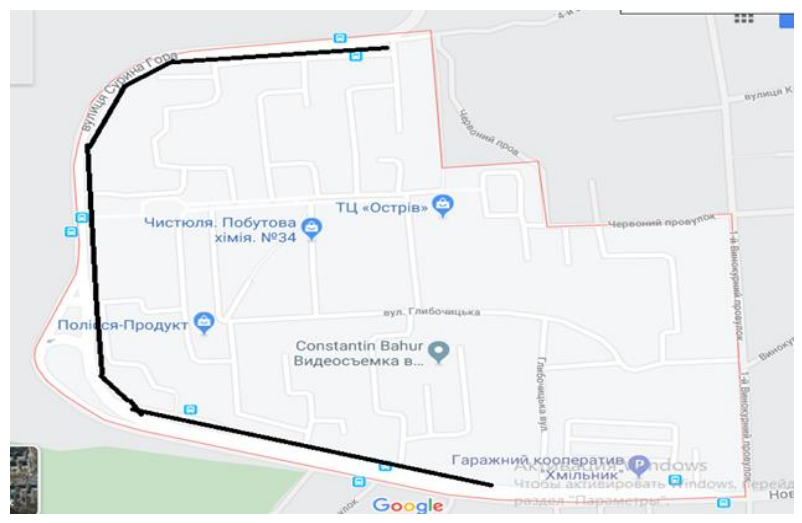

Рис. 11. Розмішення екрана у мікрорайоні Хмільники згідно з варіантом № 2 та № 3

Облаштування шумозахисного екрана згідно 3 варіантом № 3 дозволяє знизити рівень звуку на території, прилеглій до джерела шуму, на 10-15 дБ. Однак такі значення можливі лише за наявності одного екранованого джерела шуму, наприклад під час екранування транспортного потоку на міжміській магістралі. В умовах мікрорайону міста транспортні засоби є основним, однак не єдиним джерелом шуму. Екранування шуму від транзитних транспортних засобів суттєво знизить шумове навантаження, однак ніякою мірою не зменшить шум, спричинений рухом транспорту всередині мікрорайону, життєдіяльністю місцевих жителів, роботою інфраструктури мікрорайону. Отже, проведені розрахунки показали, що в середньому за екраном шум знизиться на 7-8 дБ (рис. 12). При віддаленні вглиб мікрорайону рівень шуму буде зменшуватися, однак різниця між його рівнем до та після проєктування заходів буде не такою значною, як поблизу траси за рахунок накладання шумів із різних джерел та зменшення внеску транспортного шуму у загальну шумову картину.

Аналізуючи проєктні значення шумового навантаження можна зробити висновок, що запроєктований екран дозволить зменшити рівень шуму та привести його у відповідність до нормативів практично по усій досліджуваній території. Виключення - виїзд на вулицю Клосовського, який не входить до мікрорайону та відповідно не підлягав проектуванню захисних заходів та вулиця Глибочицька, яка є основними місцем заїзду транспортних засобів на територію мікрорайону та не може бути екранована суцільним екраном. Крім того, ця територія практично не містить ландшафтних екрануючих елементів. Вона є рівнинною із невеликою кількістю дерев, будівлі розташовані далі углиб мікрорайону і розміщені перпендикулярно до звукової хвилі.

Тому для цієї частини мікрорайону, окрім встановлення шумопоглинаючого екрана, доцільним буде проведення озеленення території із висадженням дерев, що мають значні шумопоглинаючі властивості: клен, липа тощо [15]. Однак варто враховувати, що для досягнення деревами необхідних розмірів потрібен певний час і навіть після проведення відповідних заходів нормативного рівня шуму у мікрорайоні буде досягнуто не одразу. 
Висновки. Зниження рівня автотранспортного шуму забезпечується різноманітними способами, у тому числі архітектурно-акустичними. Практика боротьби з шумом показує, що ефективним та якісним колективним засобом захисту є акустичні екрани, що встановлюються вздовж транспортних магістралей.

Проведено розрахунки шумової характеристики транспортного потоку та побудовано карти шуму в мікрорайоні Хмільники.

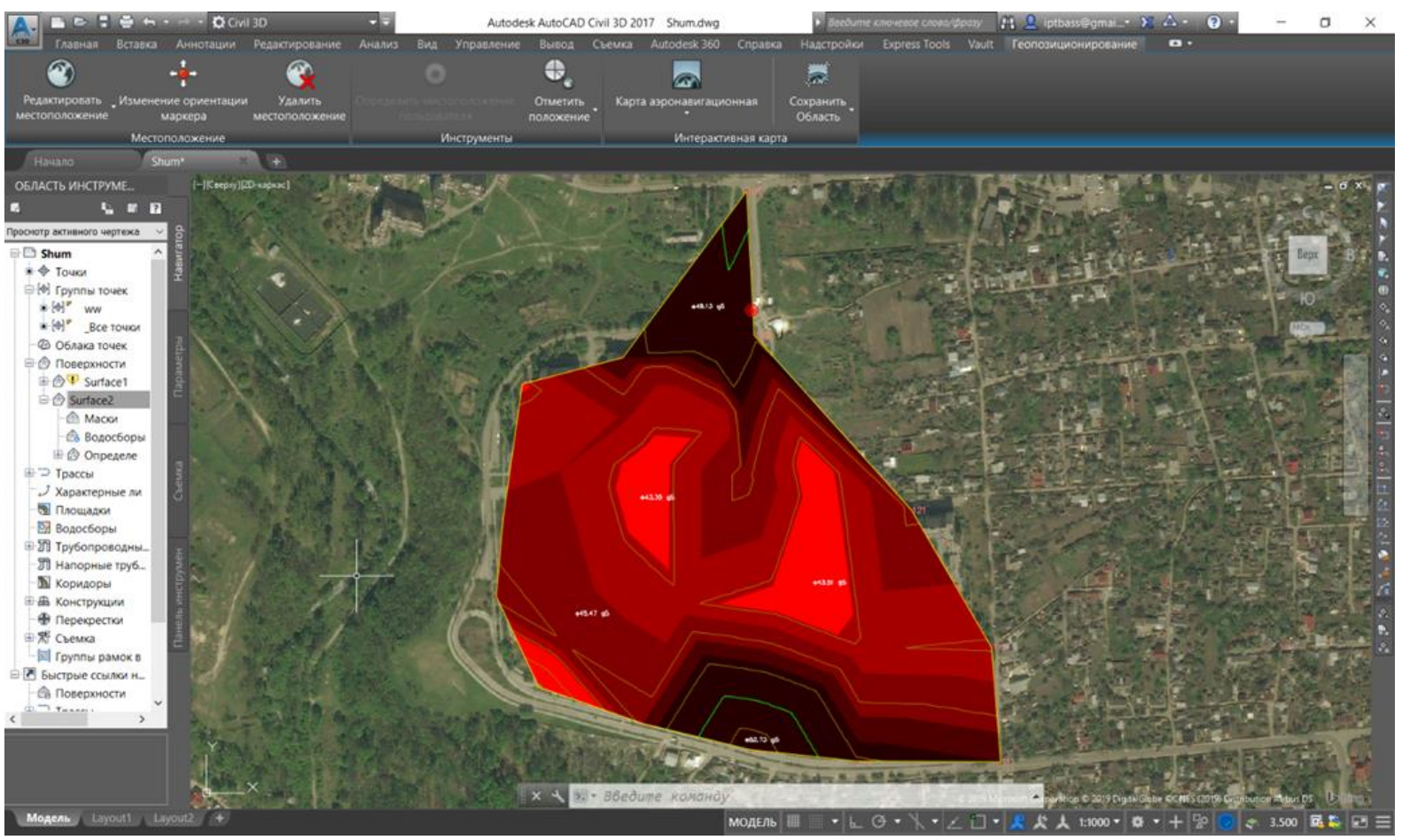

Рис. 12. Проєктна карта рівня шумового навантаження в мікрорайоні Хмільники після встановлення шумопоглинаючого екрана

За результатами розрахунків визначено житлові території з наднормовими рівнями шуму. У зв'язку з цим запропоновано місце встановлення шумозахисного екрана навколо району як дієвого, і єдино можливого засобу зниження шуму в такій ситуації.

За результатами акустичних розрахунків визначено геометричні параметри екранів, надано вимоги щодо акустичних характеристик конструкції екрана і запропоновано базові конструкції, що відповідають таким характеристикам. Розрахункова ефективність екранів становить 7-8 дБ.

\section{Список використаної літератури:}

1. Шумове забруднення // Журнал ECOBUSINESS [Електронний ресурс]. - Режим доступу : http://ecologua.com/articles/shumove-zabrudnennya

2. Маслов Н.В. Градостроительная экология / Н.В. Маслов ; под ред. М.С. Шумилова. - М. : Высшая школа, 2002. $-284 \mathrm{c}$

3. Ткачишин В.C. Вплив виробничого шуму на організм людини : автореф. дис. на здобуття наук. ступеня канд. наук / В.С. Ткачишин; Національний медичний університет ім. О.О. Богомольця. - Київ, 2014.

4. Решетченко A.I. Дослідження впливу автотранспортних потоків на акустичне середовище урболандшафтів / A.I. Решетченко // Комунальне господарство міст. - 2018. - № 7 (146).

5. Бичковський O.B. Проблема шумового забруднення у містах / O.B. Бичковський // Вісник Національного університету водного господарства та природокористування. - 2014. - № 4 (52). - С. 218-224.

6. Бакуліч O.O. Соціально-економічне обгрунтування впливу шумозахисних заходів на навколишнє середовище / О.О. Бакуліч, О.С. Левіщенко, Д.К. Левіщенко // Вісник Національного транспортного університету. - 2016. - № 1 .

7. Абрамов В.М. Захист населених пунктів від транспортного шуму / В.М. Абрамов, Д.Ф. Оболонков // Збірник наукових праць ДонНАБА. - 2016. - № 4.

8. Технічні бар'єри [Електронний ресурc]. https://studme.com.ua/19350317/menedzhment/tehnicheskie_barery.htm.

9. Кучеренко Л.В. Містобудівні методи захисту від шумового забруднення міст / Л.В. Кучеренко, B.С. Калініченко // Сучасні технології, матеріали і конструкції в будівництві. - 2013. - № 1. - С. 103-107.

10. Шумомір [Електронний ресурс]. - Режим доступу : https://xrs.ru/shumomer-ada-zsm-130-947-detail.

11. ГОСТ 31296.2-2006 (ИСО 1996-2:2007) Шум. Описание, измерение и оценка шума на местности. Часть 2. Определение уровней звукового давления (с поправкой). - М. : Стандартинформ, 2008. - 51 с. 
12. ГОСТ 23337-2014. Шум. Методы измерения шума на селитебной территории и в помещениях жилых и общественных зданий. - М. : Стандартинформ, 2015. - 28 с.

13. Кулябко В.В. Аналіз конструктивних заходів для захисту об'єктів міської забудови від шуму / В.В. Кулябко, А.В. Черненко, Т.В. Черненко. -2018.

14. Зелені насадження - проти шумового забруднення в містах [Електронний ресурс]. - Режим доступу : http://www.novaecologia.org/voecos-1689-1.html.

\section{References:}

1. «Shumove zabrudnennia», Zhurnal ECOBUSINESS, [Online], available at: http://ecolog-ua.com/articles/shumovezabrudnennya

2. Maslov, N.V. (2002), Hradostroytelnaia ekolohyia, in Shumylov, M.S. (ed.), Vysshaya shkola, M., 284 p.

3. Tkachyshyn, V.S. (2014), «Vplyv vyrobnychogo shumu na organizm ljudyny», Abstract of dissertation, Nacional'nyj medychnyj universytet im. O.O. Bogomol'cja, Kyi'v.

4. Reshetchenko, A.I. (2018), «Doslidzhennja vplyvu avtotransportnyh potokiv na akustychne seredovyshhe urbolandshaftiv», Komunal'ne gospodarstvo mist, No. 7 (146).

5. Bychkovs'kyj, O.V. (2014), «Problema shumovogo zabrudnennja u mistah», Visnyk Nacional'nogo universytetu vodnogo gospodarstva ta pryrodokorystuvannja, No. 4 (52), pp. 218-224.

6. Bakulich, O.O., Levishhenko, O.S. and Levishhenko, D.K. (2016), «Social'no-ekonomichne obg'runtuvannja vplyvu shumozahysnyh zahodiv na navkolyshnje seredovyshhe», Visnyk Nacional'nogo transportnogo universytetu, No. 1.

7. Abramov, V.M. and Obolonkov, D.F. (2016), «Zahyst naselenyh punktiv vid transportnogo shumu», Zbirnyk naukovyh prac' DonNABA, No. 4.

8. Tehnichni bar'jery, [Online], available at: https://studme.com.ua/19350317/menedzhment/tehnicheskie_barery.htm

9. Kucherenko, L.V. and Kalinichenko, V.S. (2013), «Mistobudivni metody zahystu vid shumovogo zabrudnennja mist», Suchasni tehnologii', materialy i konstrukcii'v budivnyctvi, No. 1, pp. 103-107.

10. Shumomir, [Online], available at: https://xrs.ru/shumomer-ada-zsm-130-947-detail

11. GOST 31296.2-2006 (ISO 1996-2:2007) Shum. Opisanie, izmerenie i otsenka shuma na mestnosti. Chast' 2. Opredelenie urovnei zvukovogo davleniya (s popravkoi) (2008), Standartinform, M., 51 p.

12. GOST 23337-2014. Shum. Metody izmereniya shuma na selitebnoi territorii $i v$ pomeshcheniyakh zhilykh $i$ obshchestvennykh zdanii (2015), Standartinform, M., 28 p.

13. Kuljabko, V.V., Chernenko, A.V. and Chernenko, T.V. (2018), Analiz konstruktyvnyh zahodiv dlja zahystu ob 'jektiv mis'koi' zabudovy vid shumu.

14. Zeleni nasadzhennja - proty shumovogo zabrudnennja $\mathrm{v}$ mistah, [Online], available at: http://www.novaecologia.org/voecos-1689-1.html

Гупалюк Юрій Ігорович - студент гірничо-екологічного факультету Державного університету «Житомирська політехніка».

Наукові інтереси:

- промислова екологія;

- раціональне природокористування.

Шомко Дарина Василівна - студентка гірничо-екологічного факультету Державного університету «Житомирська політехніка».

Наукові інтереси:

- лісівництво;

- раціональне природокористування.

Шомко Віта Вікторівна - студентка гірничо-екологічного факультету Державного університету «Житомирська політехніка».

Наукові інтереси:

- лісівництво;

- промислова екологія.

Носик Оксана Василівна - студентка гірничо-екологічного факультету Державного університету «Житомирська політехніка».

Наукові інтереси:

- екологічна безпека;

- безпека життєдіяльності.

Давидова Ірина Володимирівна - доцент кафедри екології Державного університету «Житомирська політехніка», кандидат сільськогосподарських наук, доцент.

Наукові інтереси:

- лісівництво;

- промислова екологія;

- радіоекологія. 